\title{
Extraction of Nanoparticles from Dandelion grass (Chicory) for Cooling the Photovoltaic Solar Cell with Green Nanofluid
}

\author{
Mousa M. Mohamed ${ }^{1}$, M.Abd Elshokary ${ }^{2}$, Rifai I. Rifai ${ }^{3}$, M. F Azzazy ${ }^{3}$ \\ ${ }^{1}$ Mechanical Power Engineering, Faculty of Engineering, Menoufia University, Shebin El Kom, \\ Egypt, \\ ${ }^{2}$ Researcher, Institute of Environmental Studies and Research, University of Sadat City, Egypt \\ ${ }^{3}$ Environmental Studies and Research Institute, University of Sadat City, Egypt \\ (Corresponding author: mohamed.elshokery@usc.edu.eg)
}

\begin{abstract}
The experiments have been carried out to compares the effects of surface cooling by a thin continuous film of tap water, distilled water and nanofluid (distilled water and chicory nanoparticles). The nanoparticles mixed with distilled water with various concentrations of nanofluids such as $0.01 \%, 0.03 \%$ and $0.05 \%$ running on the front of the PV module to investigate the performance of photovoltaic solar system. Data obtained from the elemental composition analysis of green chicory revealed the presence of 23 elements with nano size. The formation of potassium chloride nanoparticles was confirmed by X-Ray Diffraction, XRD, with average crystallite size $20 \mathrm{~nm}$, which is in agreement with Transmission Electron Microscpe, TEM, analysis Scanning Electron Microscope, SEM, analysis shows the aspheric potassium chloride and other minerals nanoparticles [1]. It was found that Nanofluid has more effect on improving the panel performance than pure water. The average output power of the PV module increased from $3.83 \%$ to $7.95 \%$ with increasing the cooling flow rate of tap water from 0.275 to $0.85 \mathrm{~L} / \mathrm{min}$ and distilled water from $5.67 \%$ to $7.94 \%$ with flow rate of 0.75 to $0.85 \mathrm{~L} / \mathrm{min}$ compared without cooling. But for nanofluid of $0.95 \mathrm{~L} / \mathrm{min}$ with concentration of $0.01,0.03,0.05 \%$ nanoparticles, the average output power were increased from $8.023 \%$ to $8.816 \%$ by about $10 \%$. The average improvements of daily back surface temperature of PV is found about $30 \%$ at cases of distilled water with flow rate of $0.95 \mathrm{~L} / \mathrm{min}$ and nanofluid with concentration of $0.05 \%$.
\end{abstract}

Keywords: Chicory, photovoltaic system, cooling, Green nanofluid, photovoltaic performance

\section{Introduction}

Developing clean and renewable energy has become one of the most important tasks in the field of modern science and engineering. Solar energy can be recognized as one of the most promising renewable energy sources. Photovoltaic, PV, solar systems, presently is accepted as the most important way to convert solar energy into electricity, due to pollutionfree and profusely available anywhere in the world. PV systems performance in the outdoor are affected by many factors; these factors are occurred mainly by environmental features and weather conditions as irradiance, wind, temperature, humidity and dust. PV module is highly affected by ambient temperature PV module temperature increases more than the Standard Test Condition (STC) temperature, which is $25^{\circ} \mathrm{C}$ decreasing voltage. Therefore, the output power of the PV module is reduced [2]. Increasing PV module temperature leads to PV module voltage and current decreasing. Previous researches and experiments include many studies to improve the performance of PV cell by various cooling system design and by different cooling methods such as air, water and nanofluids cooling. The application of photovoltaics is very wide including water pumping, remote buildings, solar home systems, communications, satellites, space vehicles and for large power plants. Owing to this capability, the demand for photovoltaics is increasing all over the world and has begun to become economically competitive with conventional energy sources [3]. Although irradiation is the main indicator of PV potential, it is also necessary to consider secondary parameters such as PV technology, environmental parameters (wind, temperature, and humidity) which allowed us to quantify with precision the amount of electricity produced by a PV system. [4]. Temperature affects how electricity flows through an electrical circuit by changing the speed at which the electrons travel [56]. This is due to an increase in resistance of the 
circuit that results from an increase in temperature likewise, resistance is decreased with decreasing temperatures. The power incident on a PV module depends not only on the power contained in the sunlight, but also on the angle between the module and the sun rays [7]. When the absorbing surface and the sunlight are perpendicular to each other, the power density on the surface is equal to that of the sunlight. However, tilting the surface up, causes the diffuse light to decrease. A good orientation and tilt angle of PV modules can maximize its energy potential [8]. For the best performance of the systems in the year, in most locations, fixed PV modules should be oriented to true south (in the Northern Hemisphere). In the case that there is no possibility to move the surface of the PV modules at all, the optimal tilt angle for the maximum amount of direct irradiance is set out to the site's latitude [8].Cooling techniques of photovoltaic (PV) panels in general, are analyzed and discussed. Namely, it is well known that a decrease in the panel temperature will lead to an increase in electrical efficiency, so in recent years different cooling techniques have been proposed and tested experimentally. The efficiency drops with the rise in temperature, with a magnitude of approximately $0.5 \% /{ }^{\circ} \mathrm{C} \quad[9]$. Several cooling techniques have been tried, mostly based on active water and air cooling, as these are the simplest techniques. Other cooling techniques include conductive cooling, phase-change material cooling, etc. Increase in electrical efficiency depends on cooling techniques, type and size of the module, geographical position and the season of the year, and usually corresponds with a rise of 3-5\% in overall efficiency [10]. Finally, a perspective on the cooling techniques for PV panels will be also elaborated on and discussed, Two types of cooling can be distinguished: active cooling, which consumes energy (pump, fan, etc.,) and passive cooling, which uses natural convection/conduction to enable heat extraction: Nanofluids are considered to be dispersed mixtures of cooling fluid and solid nanoparticles. Most of the particles used are metal oxides, for example $\mathrm{Al}_{2} \mathrm{O}_{3}$ or $\mathrm{TiO}_{2}$ or $\mathrm{CuO}$ or $\mathrm{ZnO}$ particles. Weight percentage of dispersed particles is around 0.1-2.0\%. The particles have brownian motion through cooling fluid. Main advantages of Nanofluids are greater thermal conductivity (therefore connectivity) and somewhat greater heat capacity [11]. Chicory is called dandelion grass or so-called in Egypt Alseris and is found in a large number of agricultural clover and vegetables as shown in Figure1. Despite of the plant is not desirable in the cultivation of alfalfa because it takes place from the place of Alfalfa, and the farmer wants alfalfa widely to fatten cattle. The Chicory or the throne has medical benefits. Large Seris is useful for patients with liver, sugar and diuretic. Also, Alseris is useful for kidneys as diearitic, it burns fat and is used for slimming and the amount of fiber beneficial for colon. Chicory root has a long history of human use, both as a food and as a dietary supplement to control high blood sugar levels. This activity is attributed to high amounts of the inulin-type fructans that slow down carbohydrate digestion and glucose absorption in the gastrointestinal tract [12]. Chicory plants also produce a variety of other bioactive secondary metabolites, including caffeoylquinic acids and caffeic acid derivatives as major phenolic constituents [13].

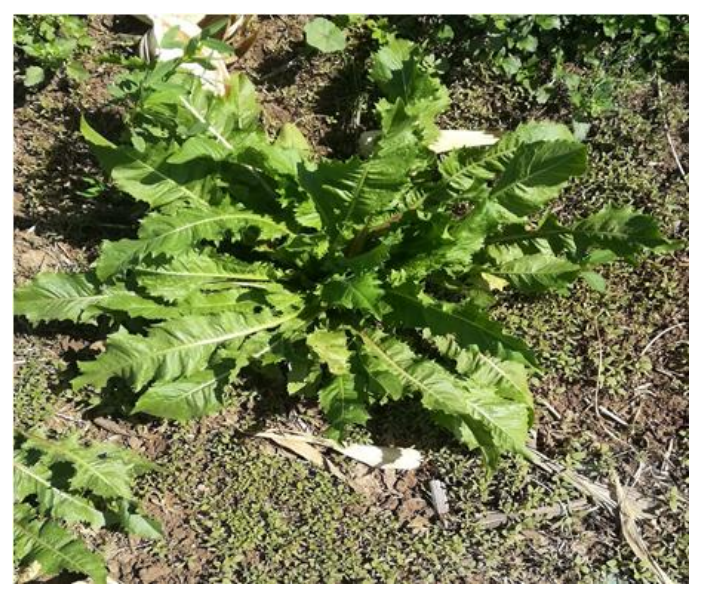

Figure 1- Chicory herb or so-called in our country Egypt Alseris

$\mathrm{Xu}$ and Kleinstreuer [14] made a numerical model for water and nanofluid cooling of silicon PV cells and showed the cooling potential of nanofluid to be somewhat greater than that of water. Electrical efficiency seems to maintain higher values even at increased temperatures when PV panel is cooled with nanofluids. The efficiency difference between water and nanofluid cooling is significant during higher outlet fluid temperatures, and it can be up to $1 \%$ of total efficiency. Sardarabadi et al. [15] used copper tubing to cool down a $40 \mathrm{~W}$ polycrystalline PV module from back side. Cooling fluid was water and two nanofluids with silica particles. Content of particles was $1.0 \%$ and $3.0 \%$ of weight respectively. Maximum fluid flow was $0.011 \mathrm{~kg} / \mathrm{sec}$. It was shown that nanofluid with $3.0 \%$ wt. of particles enhances the efficiency by nearly $1.5 \%$, when compared with water cooling. Presumed surface of $40 \mathrm{~W}$ PV module is $0.35 \mathrm{~m}^{2}$. Al-Busoul et al. [16] studied the performance of a cooled $\mathrm{PV}$ module by using $\mathrm{Al}_{2} \mathrm{O}_{3}$ and $\mathrm{TiO}_{2}$ nanofluids with different concentrations under local conditions. It has been found that there is a significant increase in both of output power and 
final efficiency of all tested modules when nanofluids employed to cool down the PV module. The highest possible enhancement, under the local testing conditions, was observed for a nanofluid based on $\mathrm{Al}_{2} \mathrm{O}_{3}$ with a concentration of $0.02 \%$ by wt. Hussein, Hashim et al. [17] presented the improvement of the performance of the photovoltaic panels under Iraqi weather conditions. The biggest problem is the heat stored inside the PV cells during operation in summer season. A new design of an active cooling technique which consists of a small heat exchanger and water circulating pipes placed at the PV rear surface is implemented. Nanofluids $\left(\mathrm{Zn}-\mathrm{H}_{2} \mathrm{O}\right)$ with five concentration ratios $(0.1,0.2,0.3,0.4$, and $0.5 \%)$ are prepared and optimized. The experimental results showed that the increase in output power is achieved. It was found that, without any cooling, the measuring of the PV temperature was $76^{\circ} \mathrm{C}$ on 12 June 2016; therefore, the conversion efficiency does not exceed more than $5.5 \%$. The photovoltaic/ thermal system was operated under active water-cooling technique. The temperature dropped from 76 to $70^{\circ} \mathrm{C}$. This led to increase in the electrical efficiency of $6.5 \%$ at an optimum flow rate of $2 \mathrm{~L} / \mathrm{min}$, and the thermal efficiency was $60 \%$. While using a nanofluid ( $\mathrm{Zn}$ $\mathrm{H}_{2} \mathrm{O}$ ) optimum concentration ratio of $0.3 \%$ and a flow rate of $2 \mathrm{~L} / \mathrm{min}$, the temperature dropped more significantly to $58^{\circ} \mathrm{C}$. This led to the increase in the electrical efficiency of $7.8 \%$. The current innovative technique approved that the heat extracted from the PV cells contributed to the increase of the overall energy output. Mahmoud et al. [18] investigated experimentally of a thermal storage system consisted of an insulated water tank, a recirculation pump and a flat plate solar collector. Additionally, the effect of adding $\mathrm{ZnO}$ nanoparticles to the working fluid was tested. The results showed that, the storage tank temperature is attained to about $80^{\circ} \mathrm{C}$ in summer. The average stored energy is attained maximum to 16.11 $\mathrm{MJ} /$ day in summer, and minimum to $10.26 \mathrm{MJ} /$ day in autumn. The average yearly stored energy is attained to about $13.69 \mathrm{MJ} /$ day. Zinc Oxide nanoparticles with average diameter of $23 \mathrm{~nm}$ has been added to the tap water to perform the nanofluid with volume fractions of $0.05 \%$ and $0.1 \%$. The stored energy is increased by $3.36 \%$ and $7.78 \%$ for volume fraction of $0.05 \%$ and $0.1 \%$, also the daily efficiency is increased by $4.81 \%$ and $6.57 \%$, for volume fraction of $0.05 \%$ and $0.1 \%$ compared to without nanoparticles. Based on the previous review, less attention of studying the cooling performance of photovoltaic solar cell using green nanoparticles.

\section{Aim and Research Significance}

This work aims to investigate the cooling process by a front thin continuous film of tap water, distilled water and green nanofluid (distilled water with chicory extract ash) at different flow rates with various concentrations of nanoparticles and to investigate the average increase in output power and the back surface of PV module in both cases of cooling and without cooling. The advantage of this cooling system, in addition to decreasing the temperature of the PV modules, is in obtaining better thermal efficiency due to decreasing the reflection loss, cleaning the PV solar cell from dust, reduce the cost of maintenance and increasing life cycle.

\section{Experimental set-up}

This study was conducted at Environmental Studies and Research Institute, University of Sadat City, Sadat City, Menoufia-Egypt, at latitude of N 30 $2^{\prime}$ 41.1864", and longitude of E $31^{\circ} 14^{\prime} 8.1636 "$, during the summer season, June, July and August 2020. Four methods were chosen for testing extracted ash properties. These four methods are chemical an $\mathbf{1}$; carried out by Inductive Coupled Plasma- ....... Spectra (ICP-MS), That is a powerful tool for analyzing trace metals inenvironmental samples. A large range of elements can be detected using an ICPMS.The benefits of using plasma compared to other ionization methods, such as flame ionization, are that ionization occurs in a chemically inert environment, preventing oxide formation, and ionization is more complete. Also, the temperature profile of the . torch is relatively uniform, reducing self absorption effects. The process can be broken down to four stages; sample introduction, ICP-MS [19], the samples described below were tested in environmental and food biotechnology laboratory by using NIST traceable reference equipment and materials (Merck KgaA, ICP Multi-Elements Standard Solution IV, LOT \# HC379062) in accordance with ISO/IEC 17025:2005 requirements and the methods referenced below meet ISO/IEC 17025:2005 and accreditation requirements, Sadat University, Egypt.The mineralogical composition investigated by using $\mathrm{X}$ Ray Difractometer (XRD) Bruker D2 Phaser 2nd Gen, Generator Current (mA) $10 \mathrm{~m}$, Wavelength Alpha $1.54060 \mathrm{~A}^{\circ}$, start angle 10 and end angle 70, crystal size is calculated by scherrer equation [20,21]. The samples described below were tested in environmental geology testing laboratory by using NIST traceable reference equipment and materials in accordance with ISO/IEC 17025:2017 requirements and the methods referenced below meet ISO/IEC 17025:2017 and accreditation requirements, Sadat University, Egypt Scanning Electron Microscope (SEM) analysis. The specimens were examined with a JEOL/EO-JSM-6510 LV scanning electron microscope (Jeol JEM-2100 Scanning Electron Microscope) at Electron Microscpe, Mansoura 
University, Egypt and Transmission Electron Microscpe (TEM) analysis, Perfusion or immersion fixation of the tissue using a modified solution [22]: $2.5 \%$ buffered glutaraldehyde $+2 \%$ paraformaldehyde in $0.1 \mathrm{M}$ sodium phosphate buffer $\mathrm{pH} 7.4$, leave tissue overnight at $4^{\circ} \mathrm{C}$, wash $3 \times 15$ minutes (min.) in $0.1 \mathrm{M}$ sodium phosphate buffer $+0.1 \mathrm{M}$ Sucrose, postfix 90 min. in $2 \%$ sodium phosphate buffered osmium tetroxide $\mathrm{pH} 7.4$, wash $3 \times 15 \mathrm{~min}$ in $0.1 \mathrm{M}$ sodium $\mathrm{p}$, after drying for $\sim 15$ min sections may be investigated using a transmission electron microscope . Ultrathin sections were observed at 160 $\mathrm{kV}$ using a JEOL JEM -2100 at Electron Microscpe Unit, Mansoura University, Egypt.

\subsection{Preparation of chicory extract}

Fresh chicory plant used in the study was collected from Nile Delta Clay soil in Menouf, Menoufia Governement, Egypt. Then dried according to the standard condition (under shade at low humidity at room temperature). To prepare the chicory extract, the plant was shade-dried completely, ground to powder. The Chicory powder was drenched in ethanol with concentration of 70\% [23]. The Chicory alcohol mixture was left for 7 days in a glass jar before its filtration. Then the solvent was passed through a Whatman paper filter to a flask. After that the solvent was vaporized slowly, and the highdensity liquid extract was put in the Petri dish and dried at room temperature. We put high-density chicory extract liquid in a muffle furnace at $450^{\circ} \mathrm{C}$ to convert it to ash. Figure 2 shows the chicory extract ash.

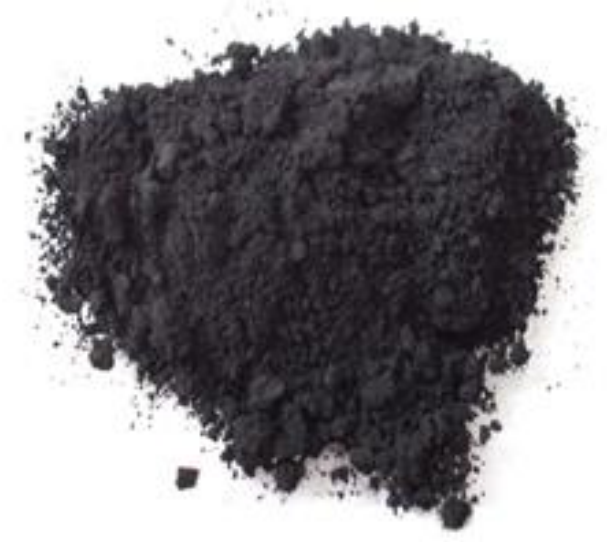

Figure 2- Chicory extract ash

\subsection{PV module cooling system setup}

In this experimental a PV module cooled by a thin continuous film of nanofluid running on the front of the panel has been considered. The experimental apparatus is relatively simple and consists of two polycrystalline PV modules that are used of area 65 $\mathrm{cm} \times 100 \mathrm{~cm}$, the PV panel consists of $9 \times 4$ cells, which have generated 100 Watts maximum power under standard test condition (STC) and typically can generate nearly 5.8A and $17.24 \mathrm{~V}$ at maximum solar radiation. We will apply the cooling system in one PV module and the other module without cooling. Figure3 shows the PV system experimental. The PV modules are south oriented at a $27 \mathrm{o}$ tilt angle (The best angle around the year). The load (lamp) is connected to the PV modules. The readings of voltage detected by Voltage sensor with voltage accuracy $\pm 0.25 \%$, current detected by ACS-712 hall effect current with current accuracy $\pm 1.5 \%$, PV module backsurface temperature detected by LM35 Sensor with accuracy $\pm 0.1^{\circ} \mathrm{C}$, ambient temperature and humidity detected by DHT11 Sensor with temperature accuracy $\pm 2^{\circ} \mathrm{C}$ and Humidity accuracy $\pm 5 \% \mathrm{RH}$ are taken with Arduino UNO microcontroller every 15 minutes starting from 9:00 am to $3: 00 \mathrm{pm}$. From the observations, it is seen that there is a constant drop in voltage and current with an increase in temperature which results in a drop in power generated. In free front flow a nanofluid (chicory extracted nanoparticles) with water cooling, the nanofluid is made to flow over the surface of the panel. The cooling system consists of a 0.75 inch PVC pipe of length $65 \mathrm{~cm}$ installed on the top end of the panel provides the nanofluid free flow on the front side of the panel to produce a film nanofluid over the PV panel. A pipe with 25 holes of $1.5 \mathrm{~mm}$ diameter has been installed on the top end of the panel to accommodate the flow of water uniformly over the surface of the panel. Nanofluid at room temperature added to the feeding pipe, leaves the holes, and flows over the panel as a thin-film. The flow rate is $0.95 \mathrm{lit} / \mathrm{min}, \mathrm{PVC}$ ball valve of $0.75 \mathrm{inch}$, hose nipple for connecting to nanofluid tank, for collecting nanofluid a 2-inch pipe of length $65 \mathrm{~cm}$ and its stopper is used. The flow of the nanofluid is controlled using the PVC ball valve.

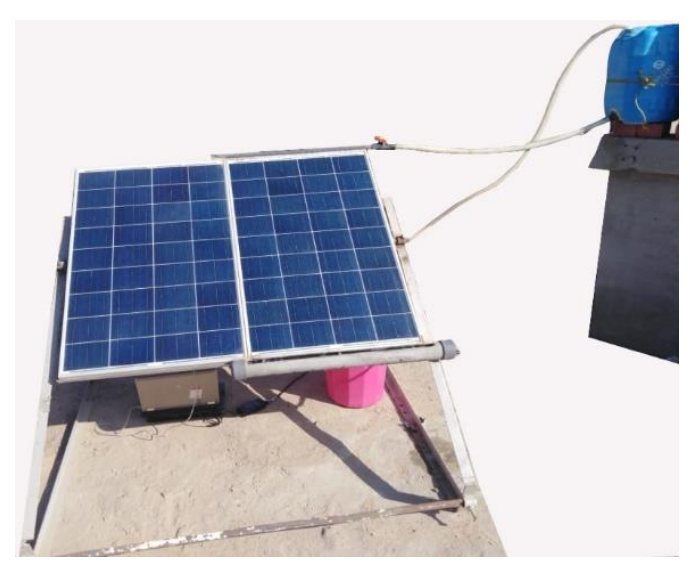

(a) Front view 


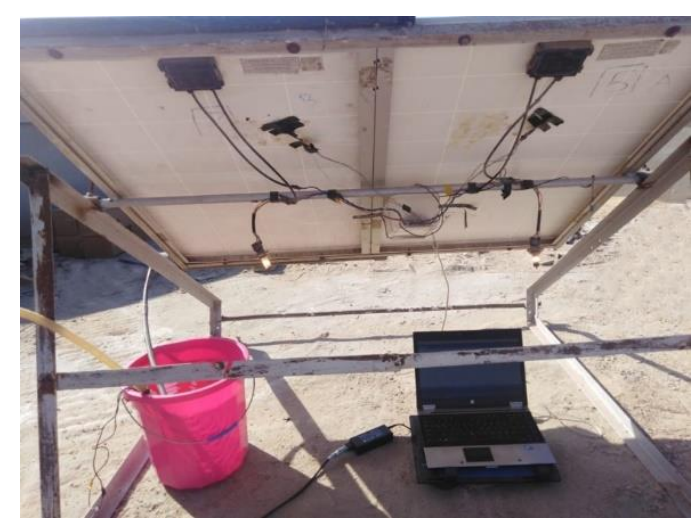

(b) Back side view

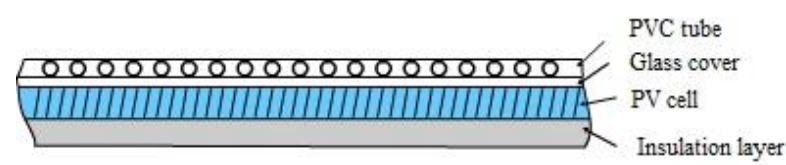

(c) Schematic diagram view

Figure 3- PV system experimental (one PV module With free front flow cooling and the other without cooling)

\section{Measurements and Results}

\subsection{Elemental composition analysis}

Elemental composition analysis, Inductive Coupled Plasma-Mass Spectra (ICP-MS) of Chicory Extract (ppm) revealed presence of 23 elements, the major elements are $\mathrm{Na} 159.59$ ppm, K 19.29 ppm, Ca 8.68 ppm, Mg $6.88 \mathrm{ppm}$ and $\mathrm{Al} 3.11 \mathrm{ppm}$. Table.1 shows the result obtained from the elements' analysis that was carried out on the chicory extract.

Table 1- Elements composition of chicory extract

\begin{tabular}{lllll}
\hline Element & $\mathrm{Na}$ & $\mathrm{K}$ & $\mathrm{Ca}$ & $\mathrm{Mg}$ \\
\hline Weight(ppm) & 159.59 & 19.29 & 8.68 & 6.88 \\
\hline Element & $\mathrm{Al}$ & $\mathrm{Cr}$ & $\mathrm{Zn}$ & $\mathrm{Fe}$ \\
\hline Weight(ppm) & 3.11 & 2.27 & 1.20 & 0.87 \\
\hline Element & $\mathrm{Sr}$ & $\mathrm{Bi}$ & $\mathrm{Ti}$ & $\mathrm{Mn}$ \\
\hline Weight(ppm & 0.85 & 0.63 & 0.56 & 0.33 \\
\hline Element & $\mathrm{Ba}$ & $\mathrm{Pb}$ & $\mathrm{In}$ & $\mathrm{Cu}$ \\
\hline Weight(ppm) & 0.32 & 0.24 & 0.15 & 0.138 \\
\hline Element & $\mathrm{B}$ & $\mathrm{N}$ & $\mathrm{Li}$ & $\mathrm{Ga}$ \\
\hline Weight(ppm) & 0.088 & 0.085 & 0.035 & 0.031 \\
\hline Element & $\mathrm{Ag}$ & $\mathrm{Co}$ & $\mathrm{Cd}$ & \\
\hline Weight(ppm) & 0.028 & 0.927 & 0.006 & \\
\hline
\end{tabular}

\subsection{Chicory extract ash analyzes results}

According to analyses conducted we found many elements in nanoparticle size such as $\mathrm{Na}, \mathrm{K}, \mathrm{Ca}, \mathrm{Mg}$, $\mathrm{Zn}$ and other elements. Data obtained revealed that the crystalline nature of nanoparticles was confirmed by X-ray crystallography as shown in Figure 4. The XRD pattern indicates that the only mineral in its composition is KCL (sylvite) with average crystallite size $20 \mathrm{~nm}$ calculated by scherrer equation [20, 21], the result crystal size shown had cubic structure .The TEM analysis shows that the chicory extract ash has an appropriate diameter in the range of the nano scale. The $50 \mathrm{~nm}$ of TEM micrograph of chicory extract ash, which explains nanoparticles with an average grain size of about $(3.15-20.73) \mathrm{nm}$ as Figure 5. The $100 \mathrm{~nm}$ of TEM micrograph of chicory extract ash, which explains nanoparticles with an average grain size of about $(5.12-22.18) \mathrm{nm}$ as Figure 6. So we expect that the nanofluid that we prepared for cooling purposes of Photovoltaic solar cell and improving it's performance.

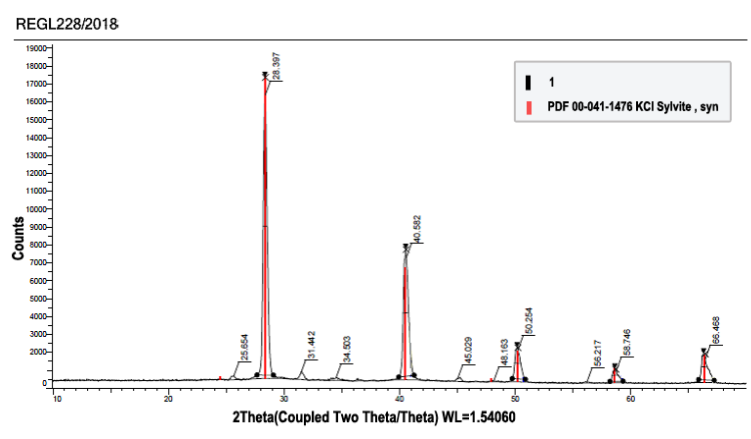

Figure 4- XRD analysis of chicory extract ash

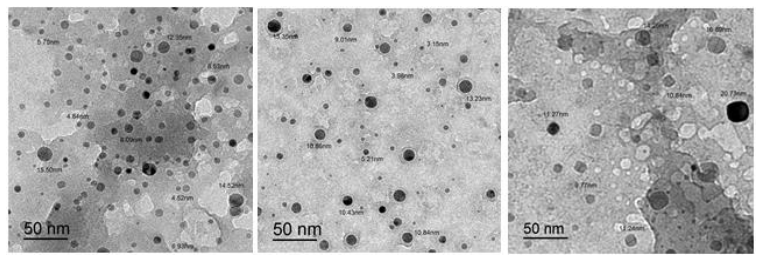

Figure 5- $50 \mathrm{~nm}$ TEM micrograph of chicory extract ash

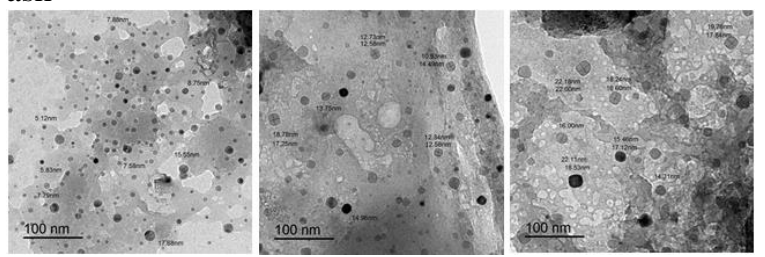

Figure 6- $100 \mathrm{~nm}$ TEM micrograph of chicory extract ash

\subsection{PV solar module cooling results}

The experiments were carried out for the PV solar module cooling using tap water experiments of volume flow rate ranging of 0.275 to $0.85 \mathrm{~L} / \mathrm{min}$. The distilled water experiments using volume flow rate within the range of 0.275 to $0.95 \mathrm{~L} / \mathrm{min}$. The green nanofluid experiments (distilled water and Chicory extract ash) of volume flow rate of $0.95 \mathrm{~L} / \mathrm{min}$ with 
three concentrations of $0.01 \%, 0.03 \%$ and $0.05 \%$ were conducted.

\subsubsection{PV solar module cooling using tap and distilled water}

In order to evaluate the performance of cooling PV module solar system with tap water, the results are plotted in figures 7 to 9 to indicate the effect of increasing surface tap water flow rate on the decreasing the PV module temperature. It is observed that, the output power of the PV module increased from $3.83 \%$ to $7.95 \%$ by increasing the flow rate by about 2 times. We can see that the surface cooling of $\mathrm{PV}$ solar module is more effective during the time period of 10:00 AM to 14:00 PM in summer and the peak cooling was occurred at noon.

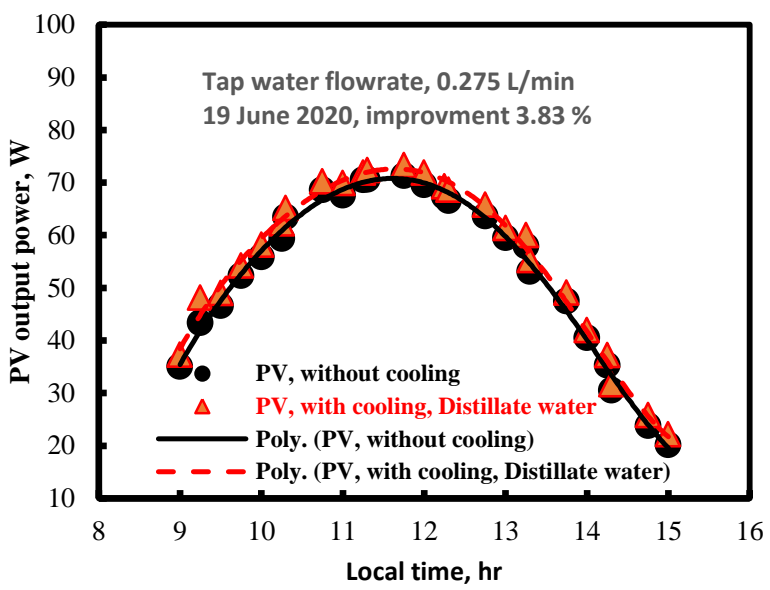

Figure 7- PV cooling module using tap water with flow rate of $0.275 \mathrm{~L} / \mathrm{min}$ with average power error without cooling $=4.64$ and average power error with cooling $=4.81$

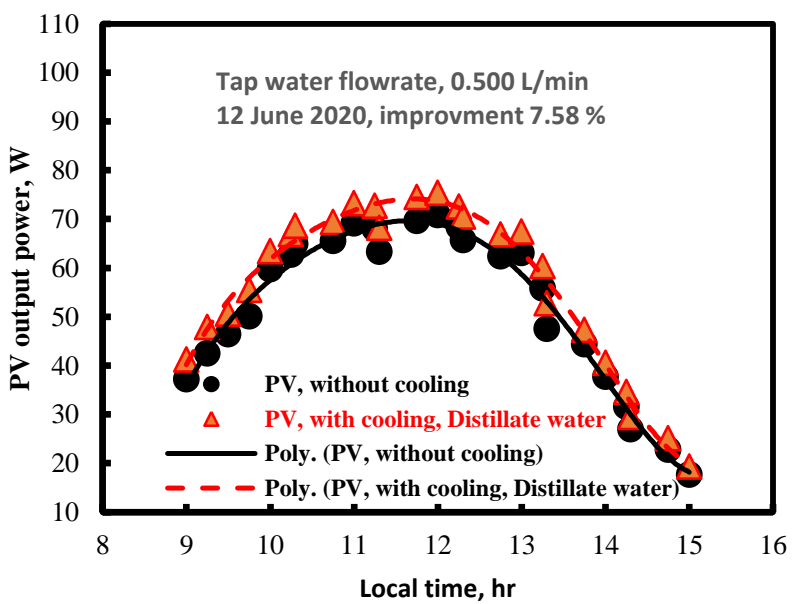

Figure 8- PV cooling module using tap water with flow rate of $0.50 \mathrm{~L} / \mathrm{min}$ with average power error without cooling $=4.58$ and average power error with cooling $=4.91$

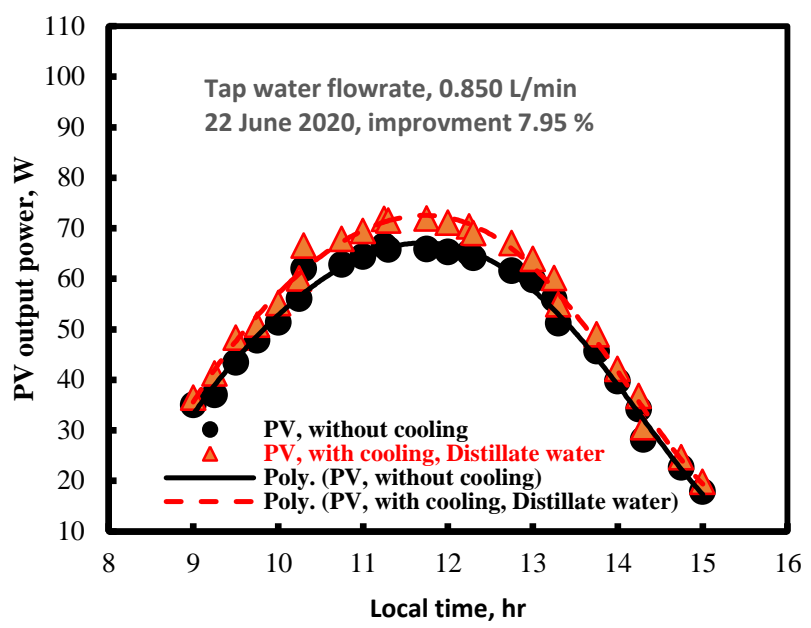

Figure 9- PV cooling module using tap water with flow rate of $0.85 \mathrm{~L} / \mathrm{min}$ with average power error without cooling $=4.39$ and average power error with cooling $=4.75$

The effect of increasing distilled water flow rate on the decreasing the surface temperature of PV solar module is shown in figures 10 and 11. It is observed that, the output power of the PV module increased from $5.7 \%$ to $7.4 \%$ by increasing the flow rate by 30 $\%$. This means that the surface cooling of PV solar module is more significant during the period of 10:00 AM to 14:00 PM and the peak was occurred at noon.

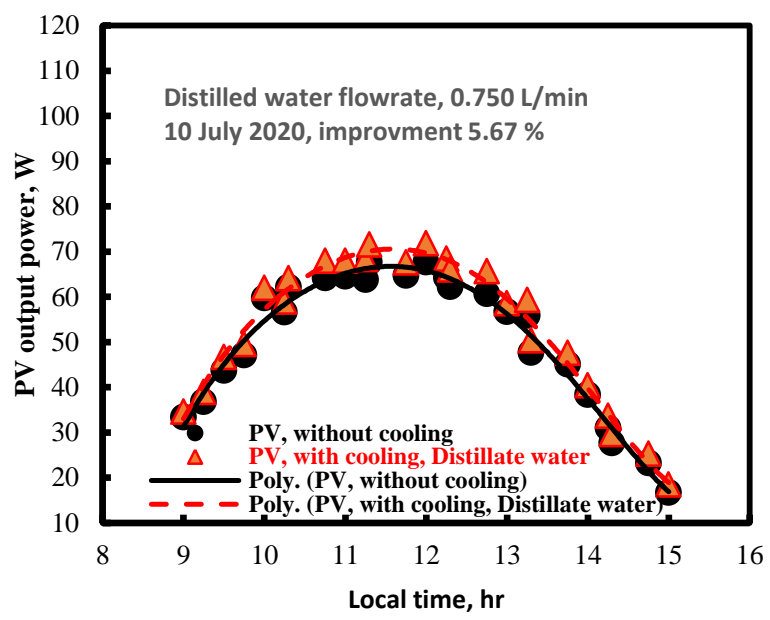

Figure 10- PV cooling module using distilled water with flow rate of $0.75 \mathrm{~L} / \mathrm{min}$ with average power error without cooling $=4.39$ and average power error with cooling $=4.63$ 


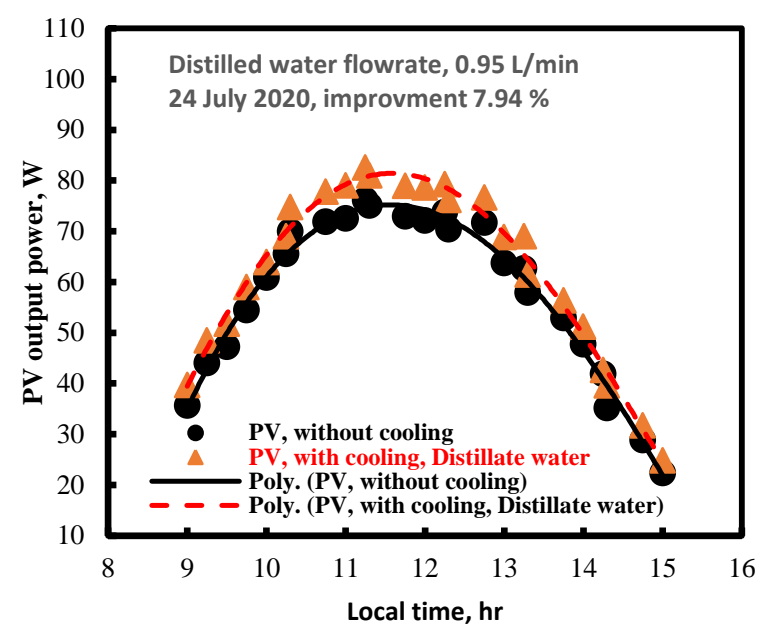

Figure 11- PV cooling module using distilled water with flow rate of $0.95 \mathrm{~L} / \mathrm{min}$ with average power error without cooling $=5$ and average power error with cooling $=5.39$

\subsubsection{PV solar module cooling using Nanofluid}

Surface cooling of PV solar module with nanofluid with concentration of $0.01,0.03,0.05 \%$ were performed at flow rate of $0.95 \mathrm{~L} / \mathrm{min}$ as shown in figures 12 to 14 . The output power was increased from $8.023 \%$ to $8.816 \%$ with increasing the concentration of nanoparticles in the base fluid.

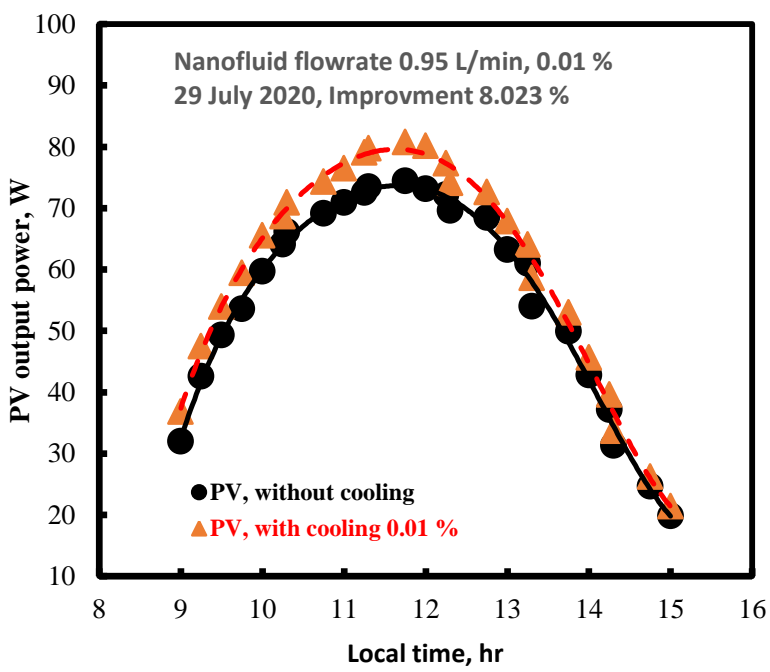

Figure 12- PV cooling module using nanofluid with concentration of $0.01 \%$ with average power error without cooling $=4.85$ and average power error with cooling $=5.23$

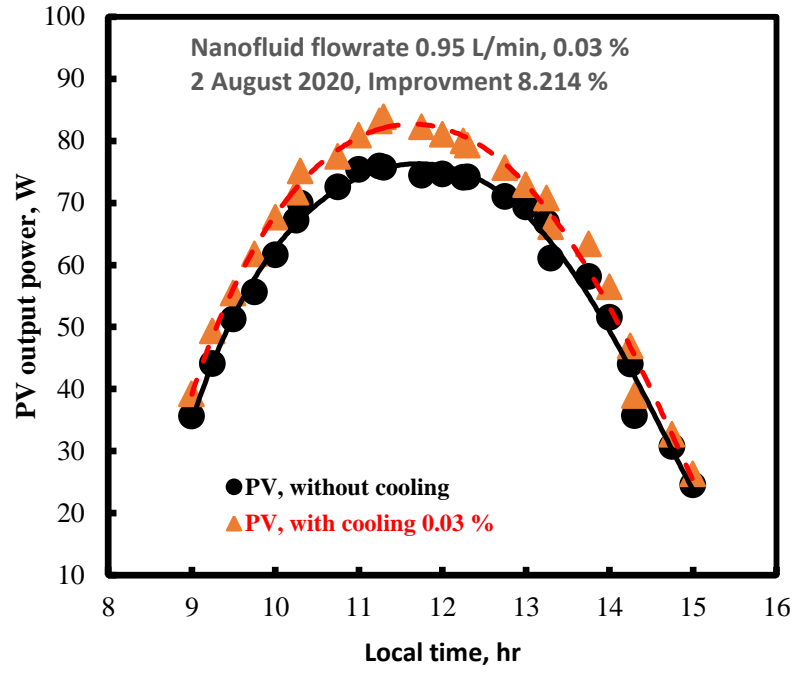

Figure 13- PV cooling module using nanofluid with concentration of $0.03 \%$ with average power error without cooling $=5.15$ and average power error with cooling $=5.57$

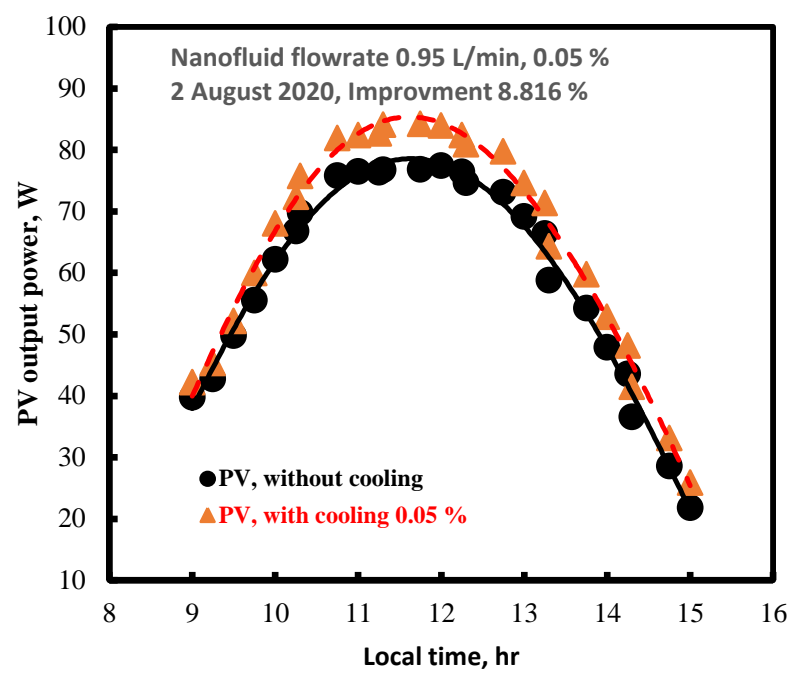

Figure 14- PV cooling module using nanofluid with concentration of $0.05 \%$ with average power error without cooling $=5.18$ and average power error with cooling $=5.62$

\subsection{Power improvement results of PV module cooling}

Figure 15 shows the surface cooling of PV solar module using nanofluid at flow rate of $0.95 \mathrm{lit} / \mathrm{min}$ with nanoparticles concentration of $0.01 \%, 0.03 \%$ and $0.05 \%$ were illustrated the increase in PV output power from $8.023 \%$ to $8.816 \%$ by about $10 \%$. 


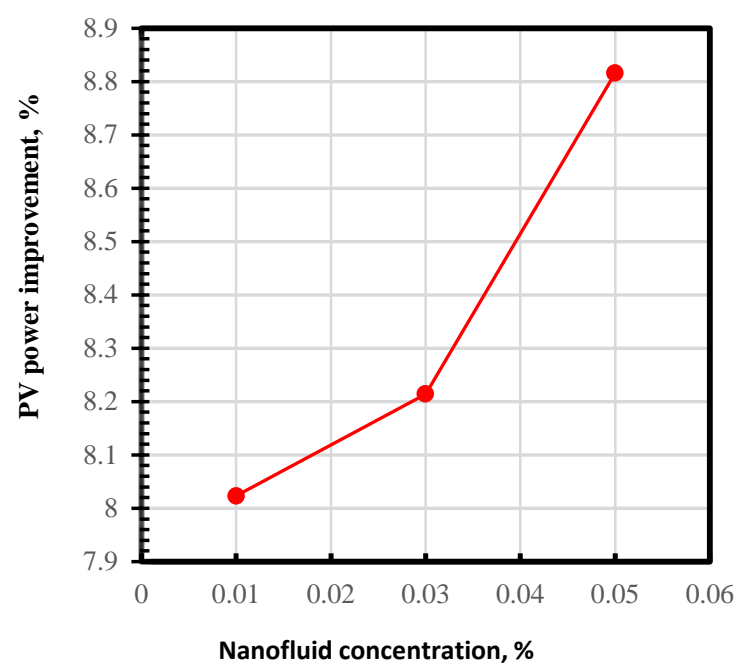

Figure $15 \mathrm{PV}$ output power percentage improvement

\subsection{Back surface temperature of solar PV systems with cooling}

The variation of back surface temperature is directly proportional to the thermal conductivity of the nanofluid. Figure 16 shows the daily variation of back surface temperature with time for distilled water and nanofluid. The best improvement with cooling of solar PV systems in cases of distilled water with flow rate of $0.95 \mathrm{~L} / \mathrm{min}$ and nanofluid with concentration of $0.05 \%$ nanoparticles. The results indicate that the daily surface temperature of the nanofluid cooling yields the lowest one and the daily average improvement is about $30 \%$. In general, increasing nanoparticle concentration have a higher heat transfer rate, because of higher thermal conductivity, uniform distribution and properly homogenous suspended in the water.

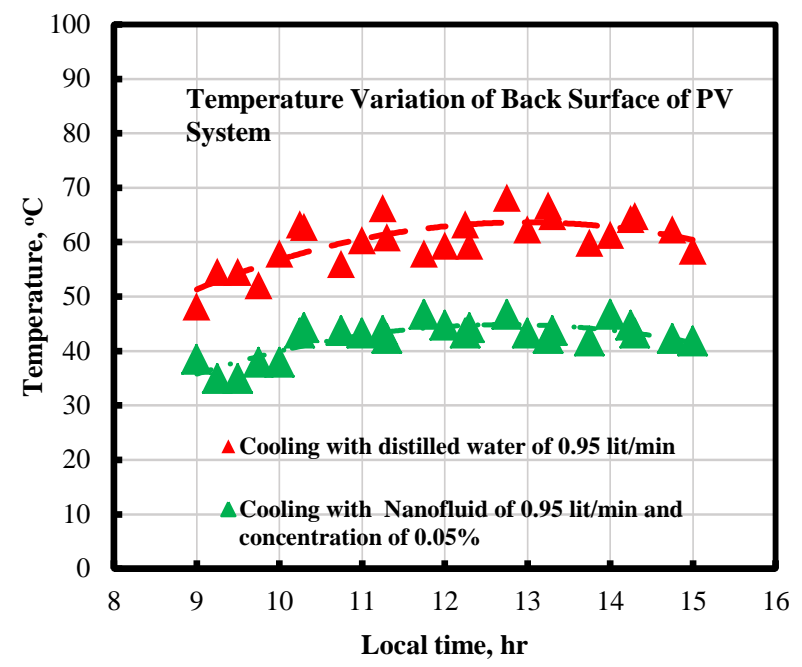

Figure 16 Back surface temperature with time for the best coaling improvement

\section{Conclusions}

In this study a PV module solar system was cooled by a front thin continuous film of tap water, distilled water and nanofluid with various concentration of chicory extract ash of $0.01 \%, 0.03 \%$ and $0.05 \%$. Based on the experimental results, the output power generated by the PV modules have been studied. The comparison has been made between the output from the PV modules with and without using the cooling system. The following results are obtained:

1. The average output power of the PV module increased from $3.83 \%$ to $7.95 \%$ with increasing the flow rate of tap water from 0.275 to 0.85 $\mathrm{L} / \mathrm{min}$.

2. The average output power of the PV module increased from $5.67 \%$ to $7.94 \%$ with increasing the flow rate of distilled water from 0.75 to 0.85 $\mathrm{L} / \mathrm{min}$ by about $30 \%$.

3. The average output power with cooling by nanofluid of $0.95 \mathrm{~L} / \mathrm{min}$ with concentration of $0.01,0.03$, and $0.05 \%$ was increased from $8.023 \%$ to $8.816 \%$ by about $10 \%$.

4. The daily average decreased of back surface temperature of PV solar module is found about $30 \%$ in the cases of nanofluid with concentration of $0.05 \%$ nanoparticles compared with distilled water at the same flow rate of $0.95 \mathrm{~L} / \mathrm{min}$.

\section{Abbreviations}

$\begin{array}{ll}\mathrm{Ag} & \text { Silver } \\ \mathrm{Al} & \text { Aluminum } \\ \mathrm{B} & \text { Boron } \\ \mathrm{Ba} & \text { Barium } \\ \mathrm{Bi} & \text { Bismuth } \\ \mathrm{Ca} & \text { Calcium } \\ \mathrm{Cd} & \text { Cadmium } \\ \mathrm{Co} & \text { Cobalt } \\ \mathrm{Cr} & \text { Chromium } \\ \mathrm{Cu} & \text { Copper } \\ \mathrm{Fe} & \text { iron } \\ \mathrm{Ga} & \text { gallium } \\ \mathrm{In} & \text { Indium } \\ \mathrm{K} & \text { potassium } \\ \mathrm{KCL} & \text { Potassium chloride (sylvite) } \\ \mathrm{Li} & \text { Lithium } \\ \mathrm{Mg} & \text { Magnesium } \\ \mathrm{Mn} & \text { Manganese } \\ \mathrm{Na} & \text { Sodium } \\ \mathrm{nm} & \text { Nanometer }\end{array}$




$\begin{array}{ll}\text { PV } & \text { Photovoltaic } \\ \mathrm{Si} & \text { silicon } \\ \mathrm{Sr} & \text { Strontium } \\ \mathrm{STC} & \text { Standard test condition } \\ \mathrm{TEM} & \text { Transmission Electron Microscope } \\ \mathrm{Ti} & \text { Thallium } \\ \mathrm{TiO} 2 & \text { Titanium dioxide } \\ \mathrm{XRD} & \text { X-Ray Diffraction } \\ \mathrm{Zn} & \text { Zinke } \\ \mathrm{ZnO} & \text { Zinc oxide }\end{array}$

\section{References}

[1] M.Abd Elshokary, Mousa M. Mohamed, Rifai I $\mathrm{R}$ and M. F Azzazy. Extraction Nanoparticles from Chicory for Cooling Purposes of Photovoltaic Solar Cell with Nanofluid . Journal of Environmental Studies and Researches (2020), 10(2 ):338-34, 2020.

[2] Dhimish, Mahmoud \& Holmes, Violeta \& Mehrdadi, Bruce \& Dales, Mark \& Mather, Peter. Output Power Enhancement for Hot Spotted Polycrystalline Photovoltaic Solar Cells. IEEE Transactions on Device and Materials Reliability. 2018. 18. 37-4510 .1109/TDMR.2017.2780224.

[3] Strong PV Demand http://www.renewableenergyworld.com /rea/news/article/2010/08/ strong-pv-demandin-2009-2010-and-2011. Web. 01 Jun 2012.

[4] Bashir, M.A., Ali, H.M., Ali, M. and Siddiqui, A.M. An Experimental Investigation of Performance of Photovoltaic Modules in Pakistan. Thermal Science, 2013.

[5] Garcı, M.C.A. and. Balenzategui, J.L. Estimation of Photovoltaic Module Yearly Temperature and Performance Based on Nominal Operation Cell Temperature Calculations. Renewable Energy, 2004.

[6] Diaf, S., Notton, G., Belhamel, M. and Haddadi, M.L.A. Design and TechnoEconomical Optimization for Hybrid PV/Wind System under Various Meteorological Conditions. Applied Energy, 2008. 85, 968-987.

[7] Pantic, S.L., Pavlovic, M.T. and Milosavljevic, D.D. A Pratical Field Study of Performances of Solar. University of Nis, Faculty of Sciences and Mathematics,
Department of Physics, Republic of Serbia, 2013.

[8] $\mathrm{Ng}$, Khai Mun \& Adam, Nor \& Inayatullah, Othman \& Kadir, Zainal. Assessment of solar radiation on diversely oriented surfaces and optimum tilts for solar absorbers in Malaysian tropical latitude. International Journal of Energy and Environmental Engineering, 2014.

[9] Soteris A. Kalogirou, in Renewable Energy Powered Desalination Handbook, 2018

[10] Grubišić-Čabo, Filip \& Nizetic, Sandro \& Tina, Giuseppe. Photovoltaic panels: A review of the cooling techniques. Transactions of FAMENA, 2016.

[11] Al-Shamani, A. N., et al., Nanofluids for improved efficiency in cooling solar collectors - A review, Renewable and Sustainable Energy Reviews 38 ,2014.

[12] Ramezan, Yousef. Investigation of inulin extraction from roots of chicory (Cichorium intybus L.), 2018.

[13] Carazzone C, Mascherpa D, Gazzani G, Papetti A. Identification of phenolic constituents in red chicory salads (Cichorium intybus) by high-performance liquid chromatography with diode array detection and electrospray ionisation tandem mass spectrometry. Food Chem, 2013.

[14] Xu, Z., Kleinstreuer, C.; Concentration Photovoltaic-thermal Energy Co-generation System using Nanofluids for Cooling and Heating, Energy Conversion and Management 87, 2014.

[15] Sardarabadi, M., Passandideh-Fard, M., Heris, S. Z., Experimental investigation of the effects of silica/water nanofluid on $\mathrm{PV} / \mathrm{T}$ (photovoltaic thermal units), Energy 66, 2014.

[16] Al-Busoul, M., Al Alawin, A., Abu Rahmeh, T., Ghrair, A., Saleh, E., Hatqawi, B., Al Abdallat, Y. and Haddad, S. Experimental Investigation on Cooling PV Modules using Nanofluids. Journal of Power Technologies, 2017.

[17] Hussein, Hashim \& Hussein Numan, Ali \& Abdulrahman, Ruaa. Improving the Hybrid Photovoltaic / Thermal System Performance 
Using Water Cooling Technique and ( $\mathrm{Zn} \mathrm{-}$ $\mathrm{H} 2 \mathrm{o})$ Nanofluid. International Journal of Photoenergy, 2017.

[18] Mahmoud N. H., Mousa M. M. and Farahat M. A., "Performance Study of A Desalination System with Thermal Storage", Engineering Research Journal, 2018.

[19] Skoog, D.A., Holler, F.J. and Crouch, S.R. Principles of Instrumental Analysis. Sixth Edition, Brooks Cole, Belmont, 2007.

[20] Scherrer P. "Bestimmung der Größe und der inneren Struktur von Kolloidteilchen mittels Röntgenstrahlen", Nachr. Ges. Wiss. Göttingen (1918), 26:98-100.

[21] J.I. Langford and Wilson, A.J.C."Scherrer after Sixty Years: A Survey and Some New Results in the Determination of Crystallite Size", J. Appl. Cryst. 1978, 11:102-113.

[22] Karnovsky, M.J. A formaldehydeglutaraldehyde fixative of high osmolality for use in electron-microscopy. Journal of Cell Biology, 1965, 27:137-138.

[23] Koleva, V., Chilev, Ch., Penchev, I., Simeonov, E., Extracting of biologically active substances from Cichorium intybus, Scientific works of UFT: "Food science, engineering and technologies". UFT Academic Publishing House, Plovdiv, 2012; 198-200 